\title{
Microbiology Research Journal International
}

20(5): 1-10, 2017; Article no.MRJI.33638

ISSN: 2456-7043

(Past name: British Microbiology Research Journal, Past ISSN: 2231-0886, NLM ID: 101608140)

\section{Effects of Water Treatment Methods on Protein Profile of Escherichia coli 0157:H7 and Escherichia coli Non-O157 Isolated from Drinking Water Sources in Ado-Ekiti, Ekiti State, Nigeria}

\author{
Busayo M. Olowe ${ }^{1 *}$, Jacob O. Oluyege ${ }^{1}$, Oladiran Famurewa ${ }^{2}$ \\ Titilayo O. Femi-Ola ${ }^{1}$, Adebayo O. Osesusi ${ }^{3}$ and Catherine O. Edward ${ }^{1}$ \\ ${ }^{1}$ Department of Microbiology, Ekiti State University, P.M.B.5363, Ado-Ekiti, Nigeria. \\ ${ }^{2}$ Department of Biological Sciences, Kings University, P.M.B. 555, Odeomu, Nigeria. \\ ${ }^{3}$ Department of Science Laboratory Technology, Ekiti State University, P.M.B.5363, Ado-Ekiti, Nigeria.
}

Authors' contributions

This work was carried out in collaboration between all authors. Author BMO designed the study, performed the statistical analysis, wrote the protocol and the first draft of the manuscript. Authors OF, JOO and TOF managed the analyses of the study. Authors AOO and COE managed the literature searches. All authors read and approved the final manuscript.

Article Information

DOI: $10.9734 / \mathrm{MRJI} / 2017 / 33638$ Editor(s):

(1) Lidija Kozacinski, Dpt. of Hygiene, Technology and Food Safety, Faculty of Veterinary Medicine, University of Zagreb, Croatia.

Reviewers:

(1) Margarita Ester Laczeski, National University of Misiones, Argentina.

(2) Stephen M. Wright, Middle Tennessee State University, USA.

(3) Alba E. Vega, Universidad Nacional de San Luis, Argentina. Complete Peer review History: http://www.sciencedomain.org/review-history/19862

Original Research Article

Received $24^{\text {th }}$ April 2017

Accepted $9^{\text {th }}$ June 2017

Published $4^{\text {th }}$ July 2017

ABSTRACT

Aim: To examine the effects of water treatment methods on the protein profile of Escherichia coli O157 and Escherichia coli non-O157 isolated from different drinking water sources in Ado-Ekiti.

Study Design: Experimental study design.

Place and Duration of Study: Department of Microbiology, Ekiti State University, Ado-Ekiti, Nigeria, between December 2015 and June 2016.

Methodology: The test organisms, E. coli 0157 and E. coli non-O157, were charged against some water treatment methods such as silver nitrate, sunlight, low and high temperature and varied $\mathrm{pH}$ 
using standard methods. Protein expression profiles of these organisms, before and after exposure, were studied with cell crude proteins extract using standard SDS-PAGE method. Statistical analysis was carried out on the data generated using correlation matrix.

Results: The survivability testing showed that E. coli 0157 survived better than E. coli non-O157. Silver nitrate, among all other agents used, exhibited the most lethal effect on both serotypes. The protein profile of the two serotypes was similar before their exposure $(r=0.9897, P$-value $=0.941)$, while after their exposure, they exhibited different characteristic responses $(r=0.693, P$-value $=$ 0.018).

Conclusion: This study showed that the treatment methods had effects on the expression of bacterial protein profile following exposure.

Keywords: Escherichia coli; physico-chemical agents; survivability; protein profile; SDS-PAGE.

\section{INTRODUCTION}

Pollution of drinking water sources is a reoccurring problem in developing countries including Nigeria [1]. Pollution or contamination of water sources could arise from point sources (such as industrial effluents and discharge from municipal waste water treatment plants) or nonpoint sources (such as runoff from farm lands, percolation of septic effluents into ground water, indiscriminate dumping of domestic wastes into streams or rivers among others) [2]. Consequently, different water treatment methods have been harnessed in different homes to combat this menace and also to ensure the safety of drinking water available. Among various water treatment methods include: The use of chlorine, sunlight (solar disinfection), silver compounds, Moringa oleifera, boiling, storage, lime, e. t. c. [3]. Unfortunately, some bacterial pathogen especially the enteric bacteria, which are mostly implicated in contaminated drinking water, have devised means of resisting some of these water treatment methods. This poses a serious threat to health of any community.

Enteric bacteria such as Escherichia coli (E. coli) which are Gram negative rod shaped bacteria within the family Enterobacteriaceae [4] has been implicated among bacteria which are capable of resisting some of these water treatment plans. This is made possible as a result of their ability to up-regulate a general stress response regulator, $\delta^{s}$, known as RpoS. Rpos is a sigma subunit of RNA polymerase which is up-regulated in $E$. coli during stationary phase and upon exposure to environmental stresses [5]. The $\delta$ s replaces the house keeping sigma factor, $\delta^{70}$, on the RNA polymerase and thus change its regulatory properties [6]. This $\delta^{s}$ polymerase recognizes a different promoter sequence which is present in front of genes that encode proteins which protect the bacteria against different types of cell injuries. Thus, allowing their survival under different water treatment methods.

The effect of environmental stresses (water treatment methods) on E. coli can be buttressed, apart from microbiological culturing method, by a molecular technique known as sodium dodecyl sulphate poly acrylamide gel electrophoresis (SDS-PAGE). This method allows for investigation of the effect of water treatment methods on the protein profile of the bacterial cell. Therefore, this study was carried out to investigate the effect of different water treatment methods such as low and high temperature, sunlight and silver nitrate and varied $\mathrm{pH}$ on the protein profile of $E$. coli $\mathrm{O} 157: \mathrm{H} 7$ and $E$. coli non0157 isolated from drinking water samples following exposure by using SDS-PAGE.

\section{MATERIALS AND METHODS}

\subsection{Bacterial Culture}

Escherichia coli 0157:H7 (S89) and non-O157 (S3b) isolated from drinking water samples and identified using PCR techniques in a previous study (Unpublished) were used in this study.

\subsection{Bacterial Growth Condition}

The bacterial cultures were sub-cultured in Tryptone Soy Broth (TSB) (Lab M, LAB011 U.K.) at $37^{\circ} \mathrm{C}$ for 24 hours and the cultures were used for the following experiments to determine the effect of different physicochemical agents on their survival as described by Albashan [7].

\subsection{Control Culture}

Each volume of $500 \mathrm{ml}$ Tryptone Soy Broth (TSB) (Lab M, LAB011 U.K.) was inoculated with an overnight culture of each of the test organisms. They were placed in a $37^{\circ} \mathrm{C}$ orbital 
shaking incubator, with constant shaking (200 rpm) for $30 \mathrm{hrs}$.

\subsection{Effect of $\mathrm{pH}$}

A volume of $500 \mathrm{ml}$ TSB each was adjusted with IM phosphate buffer to $\mathrm{pH} 5,6,7$ and 8 and was sterilized at $121^{\circ} \mathrm{C}$ for 15 minutes. Each was then inoculated with an overnight culture of the test organisms. They were placed in a $37^{\circ} \mathrm{C}$ orbital shaking incubator, with constant shaking (200 rpm) for $30 \mathrm{hrs}$.

\subsection{Effect of Low and High Temperature}

Overnight cultures of the test organisms were used to inoculate $500 \mathrm{ml}$ TSB and incubated at different high temperatures $\left(40^{\circ} \mathrm{C}, 50^{\circ} \mathrm{C}\right.$ and $60^{\circ}$ ) in an orbital shaking incubator, with constant shaking $(200 \mathrm{rpm})$ for $30 \mathrm{hrs}$. While the other inoculated broth was incubated at $4^{\circ} \mathrm{C}$ and $2^{\circ} \mathrm{C}$ using a refrigerator for $30 \mathrm{hrs}$.

\subsection{Effect of Sunlight}

An overnight culture of the test organisms was used to inoculate $500 \mathrm{ml} \mathrm{TSB}$ and was exposed to sunlight for 6 hours and after which was incubated in a shaking incubator for $30 \mathrm{hrs}$.

\subsection{Effect of Silver Nitrate}

Minimum inhibitory concentration of $0.063 \mathrm{mg} / \mathrm{ml}$ of $0.01 \mathrm{M}$ of silver nitrate was prepared and added to $500 \mathrm{ml}$ TSB. This was incubated in a $37^{\circ} \mathrm{C}$ orbital shaking incubator, with constant shaking (200 rpm) for $30 \mathrm{hrs}$.

\subsection{Determination of Survivability of the Test Organisms and Statistical Analysis of Each Test}

The bacterial survivability was determined by taking the optical density (O.D. at $600 \mathrm{~nm}$ ) of each of the test experiments at every $6 \mathrm{hrs}$ interval. The data obtained from each test experiment was analyzed using t-test to determine the correlation and significance difference (set to $5 \%$ ) between the control and the test experiments.

\subsection{Harvesting of Bacterial Protein and SDS-PAGE gel Electrophoresis}

Bacterial cells were harvested by using cold ultra centrifuge $\left(4^{\circ} \mathrm{C}\right)$ at $10,000 \mathrm{rpm}$ for $20 \mathrm{~min}$. Bacterial intracellular proteins were extracted from the cell pellets by using bacterial protein extraction reagent (Thermo Scientific) and ammonium persulfate (Sigma Aldrich) precipitation. SDS-PAGE gel electrophoresis was carried out using $12 \%$ resolving gel $(1.5 \mathrm{M}$ Tris$\mathrm{HCl}$, pH 8.8 (Bio Basic Canada, Inc), 10\% SDS (Fisher Scientific), 40\% bis-acrylamide and 4\% stacking gel (0.5 M Tris- $\mathrm{HCl}(\mathrm{pH} 6.9), 10 \%$ SDS, $40 \%$ bis-acrylamide). Bacterial proteins were treated with dithiothreitol (DTT) and boiled before it was loaded into the wells. For ease of molecular weight estimation and comparison, protein ladder (Spectra Multicolor Broad-Range Protein Ladder, Thermo Scientific) was loaded onto each gel. The SDS-PAGE gels were run using constant electric current $(30 \mathrm{~mA})$ until the bromophenol blue dye front reached the bottom of the gel plate. The protein gels were then put into a container containing staining solution, Coomassie Brilliant Blue (CBR) R-250 (Fisher Scientific). Gels were left in the staining solution overnight and also followed by overnight destaining in distilled water [8].

\subsection{Determination of Molecular Weight of Proteins and Statistical Analysis of the Protein Profile}

The molecular weight of each of the expressed bands was determined by using a molecular weight standard marker which ranged from $20 \mathrm{kDa}$ to $97 \mathrm{KDa}$. The marker comprised of five different proteins which included phosphorylate (97kDa), Bovine serum albumin $(66 \mathrm{kDa})$, Chicken ovalbumin $(45 \mathrm{kDa})$, Soyabeans trypsin inhibitor $(30 \mathrm{kDa})$ and Bovine lactoglobulin $(20 \mathrm{kDa})$. A standard graph was plotted for each of the organisms by the mobility (retention factor, $R_{f}$ ) values on the $x$-axis and logarithm of molecular weight on the $y$-axis. The molecular weight of each of the expressed bands was extrapolated from the graph. The protein banding pattern for each sample was scored for the presence and absence of bands as 1 and 0 respectively. The statistical analysis included correlation between the protein profile expressions by the test organisms.

\section{RESULTS AND DISCUSSION}

The survivability of the test organisms after every six hours was determined by taking the O. D (at $600 \mathrm{~nm}$ ) reading of each sample and this is presented in Table 1 to 3 . Table 1 depicts the survival of both $E$. coli $\mathrm{O} 157$ and $E$. coli non$\mathrm{O} 157$ following exposure to varied $\mathrm{pH}$. The result showed that the there was a strong positive correlation between the control and test experiments in the response of both organism at $\mathrm{pH} 5$ to $\mathrm{pH}$ 8. Statistically, there was a significant 
difference between the response of $E$. coli 0157 at $\mathrm{pH} 5,6$ and 8 likewise for $E$. coli non $\mathrm{O} 157$ at $\mathrm{pH}$ 8. However, there was no statistical significant difference in the response of $E$. coli non-O157 to the effect of $\mathrm{pH} \mathrm{5,6}$ and 7 when compared with the control experiment.

The result shown in Table 2 explains the response of the two test organisms to varied high and low temperatures. There was a positive correlation between the control and test experiments on both test organisms. Statistically, there was a significant difference in the response of $E$. coli $O 157$ to the effect of temperature 4, 20 and $60^{\circ} \mathrm{C}$ as the $\mathrm{p}$-values are less than 0.05 but there was no significant difference at temperature 40 and $50^{\circ} \mathrm{C}$. For E. coli non-O157, there was a statistical difference between the test and control experiments at temperature 4, 20 and $40^{\circ} \mathrm{C}$.

The treatment with sunlight and silver nitrate on both organisms reduced their survivability after exposure. The results showed that that there was a statistical significant difference in the response of both test organisms to the effect of sunlight and silver nitrate $(p$-value $<0.05)$ (Table 3$)$.

The extracted crude bacterial proteins were separated on denaturing polyacrylamide electrophoresis gel. Plate1. shows the protein expression profile of E. coli $\mathrm{O} 157$ and E. coli non-0157 respectively following exposure to various treatment conditions (Silver nitrate, sunlight, low and high temperature and $\mathrm{pH}$ ) for $30 \mathrm{hrs}$. The result shown on Plate 1 revealed the protein expression pattern of the two strains $(E$. coli non-O157 on the G-plate and E. coli O157 on the $\mathrm{H}$-plate). Comparatively, the two strains exhibited different protein expression pattern. Following exposure to different $\mathrm{pH}$, that is $\mathrm{pH} 5$ 8. It was observed that E. coli non-O157 gave a similar pattern of protein expression from GL1 to GL3. Intensity of bands were the same when compared with the control but GL4 gave a different protein expression pattern. Some bands were not expressed when compared with the control while similar protein expression pattern was observed in E. coli O157 from Lane HL1HL4.

Following exposure to varied high temperature, $40^{\circ} \mathrm{C}, 50^{\circ} \mathrm{C}$, and $60^{\circ} \mathrm{C}$, different pattern of protein expression was observed for both strains. Downstream, the intensity and broadness of bands seen in both strains were completely different from the control. At low temperature, $4^{\circ} \mathrm{C}$ and $20^{\circ} \mathrm{C}$, protein expression was poorer in E. coli non-O157 than O157. Some bands were not expressed in E. coli non-0157 when compared with the control while in E. coli O157, some protein bands were also not expressed and intensity of bands were more pronounced in comparison with the control. Exposure of E. coli O157 and non-O157 to sunlight produced almost similar protein patterns which are different when compared with their control. Some bands were not expressed and also broad and intense protein bands were obtained. Similarly, protein expression following exposure to silver nitrate was very poor in both strains as the expression of protein bands diminished and was completely different from the control.

Table 1. Effect of pH on Survival of E. coli 0157 and E. coli non-0157

\begin{tabular}{|c|c|c|c|c|c|c|c|c|c|c|}
\hline \multirow[t]{2}{*}{ Time (Hr) } & \multicolumn{2}{|c|}{$\begin{array}{l}\text { Control } \\
\text { (Optical density } \\
(\mathrm{nm})\end{array}$} & \multicolumn{2}{|c|}{$\begin{array}{l}\text { pH } 5 \text { (Optical } \\
\text { density (nm) }\end{array}$} & \multicolumn{2}{|c|}{$\begin{array}{l}\text { pH } 6 \text { (Optical } \\
\text { density }(\mathrm{nm})\end{array}$} & \multicolumn{2}{|c|}{$\begin{array}{l}\text { PH7 (Optical } \\
\text { density (nm) }\end{array}$} & \multicolumn{2}{|c|}{$\begin{array}{l}\text { pH8 (Optical } \\
\text { density }(\mathrm{nm})\end{array}$} \\
\hline & $\begin{array}{l}\text { E. coli } \\
0157\end{array}$ & $\begin{array}{l}E . \\
\text { coli } \\
\text { non- } \\
0157\end{array}$ & $\begin{array}{l}E . \\
\text { coli } \\
0157\end{array}$ & $\begin{array}{l}E . \\
\text { coli } \\
\text { non- } \\
0157\end{array}$ & $\begin{array}{l}E . \\
\text { coli } \\
0157\end{array}$ & $\begin{array}{l}E . \\
\text { coli } \\
\text { non- } \\
0157\end{array}$ & $\begin{array}{l}E . \\
\text { coli } \\
0157\end{array}$ & $\begin{array}{l}E . \\
\text { coli } \\
\text { non- } \\
0157\end{array}$ & $\begin{array}{l}E . \\
\text { coli } \\
0157\end{array}$ & $\begin{array}{l}E . \\
\text { coli } \\
\text { non- } \\
0157\end{array}$ \\
\hline 0 & 0 & 0 & 0 & 0 & 0 & 0 & 0 & 0 & 0 & 0 \\
\hline 6 & 0.362 & 0.247 & 0.248 & 0.306 & 0.311 & 0.118 & 0.125 & 0.304 & 0.316 & 0.211 \\
\hline 12 & 0.579 & 0.336 & 0.366 & 0.411 & 0.408 & 0.366 & 0.396 & 0.388 & 0.482 & 0.266 \\
\hline 18 & 0.683 & 0.469 & 0.489 & 0.532 & 0.563 & 0.502 & 0.775 & 0.469 & 0.597 & 0.403 \\
\hline 24 & 0.772 & 0.544 & 0.534 & 0.488 & 0.661 & 0.518 & 0.725 & 0.606 & 0.657 & 0.388 \\
\hline 30 & 0.846 & 0.603 & 0.577 & 0.483 & 0.603 & 0.577 & 0.756 & 0.621 & 0.608 & 0.393 \\
\hline $\begin{array}{l}\text { Pearson } \\
\text { Correlation }\end{array}$ & & & 0.99 & 0.93 & 0.98 & 0.96 & 0.93 & 0.99 & 0.98 & 0.97 \\
\hline t-test & & & 4.24 & 0.11 & 3.30 & 0.81 & 1.57 & 2.67 & 2.95 & 2.80 \\
\hline $\begin{array}{l}\text { p-value (at } \\
5 \% \text { ) }\end{array}$ & & & 0.00 & 0.45 & 0.01 & 0.22 & 0.08 & 0.02 & 0.01 & 0.01 \\
\hline
\end{tabular}


Olowe et al.; MRJI, 20(5): 1-10, 2017; Article no.MRJI.33638

Table 2. Effect of High and low Temperature on Survival of E. coli 0157 and E. coli non-0157

\begin{tabular}{|c|c|c|c|c|c|c|c|c|c|c|c|c|}
\hline \multirow[t]{2}{*}{ Time (Hr) } & \multirow{2}{*}{$\begin{array}{l}\text { Control } \\
\text { E. coli } \\
0157\end{array}$} & \multirow[b]{2}{*}{$\begin{array}{l}\text { E. coli non- } \\
0157\end{array}$} & \multirow{2}{*}{$\begin{array}{l}4^{\circ} \mathrm{C} \\
\text { E. coli } \\
0157\end{array}$} & \multirow[b]{2}{*}{$\begin{array}{l}\text { E. coli } \\
\text { non- } \\
0157\end{array}$} & \multirow{2}{*}{$\begin{array}{l}20^{\circ} \mathrm{C} \\
\text { E. coli } \\
0157\end{array}$} & \multirow[b]{2}{*}{$\begin{array}{l}\text { E. coli } \\
\text { non- } \\
0157\end{array}$} & \multirow{2}{*}{$\begin{array}{l}40^{\circ} \mathrm{C} \\
\text { E. coli } \\
0157\end{array}$} & \multirow{2}{*}{$\begin{array}{l}\text { E. coli non- } \\
0157\end{array}$} & \multirow{2}{*}{$\begin{array}{l}50^{\circ} \mathrm{C} \\
\text { E. coli } \\
0157\end{array}$} & \multirow{2}{*}{$\begin{array}{l}\text { E. coli } \\
\text { non- } \\
0157\end{array}$} & \multicolumn{2}{|l|}{$60^{\circ} \mathrm{C}$} \\
\hline & & & & & & & & & & & $\begin{array}{l}\text { E. } \\
\text { coli } \\
0157\end{array}$ & $\begin{array}{l}E . \\
\text { coli } \\
\text { non- } \\
0157\end{array}$ \\
\hline 0 & 0 & 0 & 0 & 0 & 0 & 0 & 0 & 0 & 0 & 0 & 0 & 0 \\
\hline 6 & 0.362 & 0.247 & 0.117 & 0.212 & 0.156 & 0.198 & 0.313 & 0.302 & 0.223 & 0.271 & 0.301 & 0.191 \\
\hline 12 & 0.579 & 0.336 & 0.267 & 0.239 & 0.311 & 0.275 & 0.676 & 0.446 & 0.56 & 0.339 & 0.501 & 0.302 \\
\hline 18 & 0.683 & 0.469 & 0.457 & 0.4 & 0.356 & 0.43 & 0.828 & 0.538 & 0.76 & 0.432 & 0.622 & 0.568 \\
\hline 24 & 0.772 & 0.544 & 0.552 & 0.461 & 0.482 & 0.441 & 0.852 & 0.604 & 0.771 & 0.555 & 0.681 & 0.483 \\
\hline 30 & 0.846 & 0.603 & 0.586 & 0.489 & 0.603 & 0.407 & 0.88 & 0.637 & 0.711 & 0.524 & 0.702 & 0.471 \\
\hline $\begin{array}{l}\text { Pearson } \\
\text { Correlation }\end{array}$ & & & 0.95 & 0.99 & 0.96 & 0.97 & 0.98 & 0.98 & 0.96 & 0.98 & 0.99 & 0.93 \\
\hline t-test & & & 4.76 & 3.85 & 4.67 & 2.68 & 1.78 & 3.65 & 1.04 & 0.83 & 3.78 & 0.97 \\
\hline $\begin{array}{l}\text { p-value (at } \\
5 \%)\end{array}$ & & & 0.00 & 0.01 & 0.00 & 0.02 & 0.06 & 0.01 & 0.17 & 0.22 & 0.01 & 0.18 \\
\hline
\end{tabular}


The characteristic protein profile of $E$. coli nonO157 and 0157 was seen in lane GLC and HLC respectively (Plate 1). Results shown in Fig. 1 and 2 showed the standard curve of the logarithm of molecular weight versus retention factor. The strong linear relationship $\left(r^{2}=0.984\right.$ (Fig.1) and $r^{2}=0.981$ (Fig. 2) between the proteins' molecular weight and migration distance $\left(\mathrm{R}_{\mathrm{f}}\right)$ demonstrated exceptional reliability in predicting their molecular weight. Therefore, from Fig. 1 and 2, the molecular weight of each of the expressed protein bands in both organisms was extrapolated and shown in Table 4. The protein profile of $E$. coli $\mathrm{O} 157$ demonstrated 14 proteins which ranged from
$81.66 \mathrm{kDa}$ to $16.96 \mathrm{kDa}$ likewise $E$. coli nonO157 demonstrated 14 proteins which ranged from $81.66 \mathrm{kDa}$ to $19.41 \mathrm{kDa}$. Statistically, a strong positive correlation exist between the molecular weights of the proteins of the two serotypes and that there was no statistical difference in their protein profile before exposure $(r=0.9897, P$-value $=0.941$. Comparatively, statistical analysis showed that there was a slight positive correlation in the frequency of protein bands shown in both serotypes after exposure as $r=0.693$ and that there was a statistical difference between the two serotypes ( $P$-values $=0.018)$ in their responses to the environmental stress.

Table 3. Effect of Sunlight of Survival of E. coli 0157 and E. coli non-0157

\begin{tabular}{|c|c|c|c|c|c|c|}
\hline \multirow[t]{2}{*}{ Time (Hr) } & \multicolumn{2}{|l|}{ control } & \multicolumn{2}{|l|}{ Sunlight } & \multicolumn{2}{|l|}{$\begin{array}{l}\text { Silver } \\
\text { nitrate }\end{array}$} \\
\hline & E. coli 0157 & $\begin{array}{l}\text { E. coli } \\
\text { non-0157 }\end{array}$ & E. coli 0157 & $\begin{array}{l}\text { E. coli } \\
\text { non-0157 }\end{array}$ & E. coli 0157 & $\begin{array}{l}\text { E. coli } \\
\text { non-0157 }\end{array}$ \\
\hline 0 & 0 & 0 & 0 & 0 & 0 & 0 \\
\hline 6 & 0.362 & 0.247 & 0.104 & 0.167 & 0.238 & 0.209 \\
\hline 12 & 0.579 & 0.336 & 0.116 & 0.171 & 0.311 & 0.284 \\
\hline 18 & 0.683 & 0.469 & 0.218 & 0.396 & 0.466 & 0.411 \\
\hline 24 & 0.772 & 0.544 & 0.453 & 0.419 & 0.533 & 0.463 \\
\hline 30 & 0.846 & 0.603 & 0.502 & 0.448 & 0.578 & 0.485 \\
\hline $\begin{array}{l}\text { Pearson } \\
\text { Correlation }\end{array}$ & & & 0.86 & 0.97 & 0.98 & 0.99 \\
\hline t-test & & & 4.39 & 3.96 & 4.32 & 3.55 \\
\hline $\begin{array}{l}\text { p-value (at } \\
5 \% \text { ) }\end{array}$ & & & 0.00 & 0.01 & 0.03 & 0.01 \\
\hline
\end{tabular}

Table 4. Molecular Weight of the Different Expressed Protein Bands of E. coli 0157 and $E$. coli non-0157

\begin{tabular}{lllllll}
\hline & E. coli O157 & \multicolumn{2}{l}{ E. coli non-0157 } & Statistical Value \\
\hline & $\begin{array}{l}\text { Retention } \\
\text { Factor }\left(\mathbf{R}_{\mathbf{f}}\right)\end{array}$ & $\begin{array}{l}\text { Molecular } \\
\text { Weights } \\
(\text { KDA })\end{array}$ & $\begin{array}{l}\text { Retention } \\
\text { Factor }\left(\mathbf{R}_{\mathfrak{f}}\right)\end{array}$ & $\begin{array}{l}\text { Molecular } \\
\text { Weights } \\
(\text { KDA })\end{array}$ & $\begin{array}{l}\text { Correlation } \\
(\boldsymbol{r})\end{array}$ & $\begin{array}{l}\text { Significance } \\
\text { at 5\% }(\boldsymbol{P} \text { - } \\
\text { value) }\end{array}$ \\
\hline 1 & 0.11 & 81.65072 & 0.11 & 81.65824 & 0.9897 & 0.941 \\
2 & 0.19 & 69.63699 & 0.18 & 71.77943 & & \\
3 & 0.28 & 58.22105 & 0.22 & 66.68068 & & \\
4 & 0.32 & 53.76752 & 0.34 & 53.45644 & & \\
5 & 0.38 & 47.71775 & 0.41 & 46.98941 & & \\
6 & 0.42 & 44.06766 & 0.45 & 43.65158 & & \\
7 & 0.46 & 40.69678 & 0.51 & 39.08409 & & \\
8 & 0.52 & 36.11769 & 0.55 & 36.30781 & & \\
9 & 0.58 & 32.05384 & 0.6 & 33.11311 & & \\
10 & 0.64 & 28.44723 & 0.67 & 29.10717 & & \\
11 & 0.71 & 24.74913 & 0.88 & 19.76970 & & \\
12 & 0.77 & 21.96443 & 0.78 & 23.76840 & & \\
13 & 0.83 & 19.49306 & 0.86 & 20.51162 & & \\
14 & 0.9 & 16.95899 & 0.89 & 19.40886 & & \\
\hline
\end{tabular}



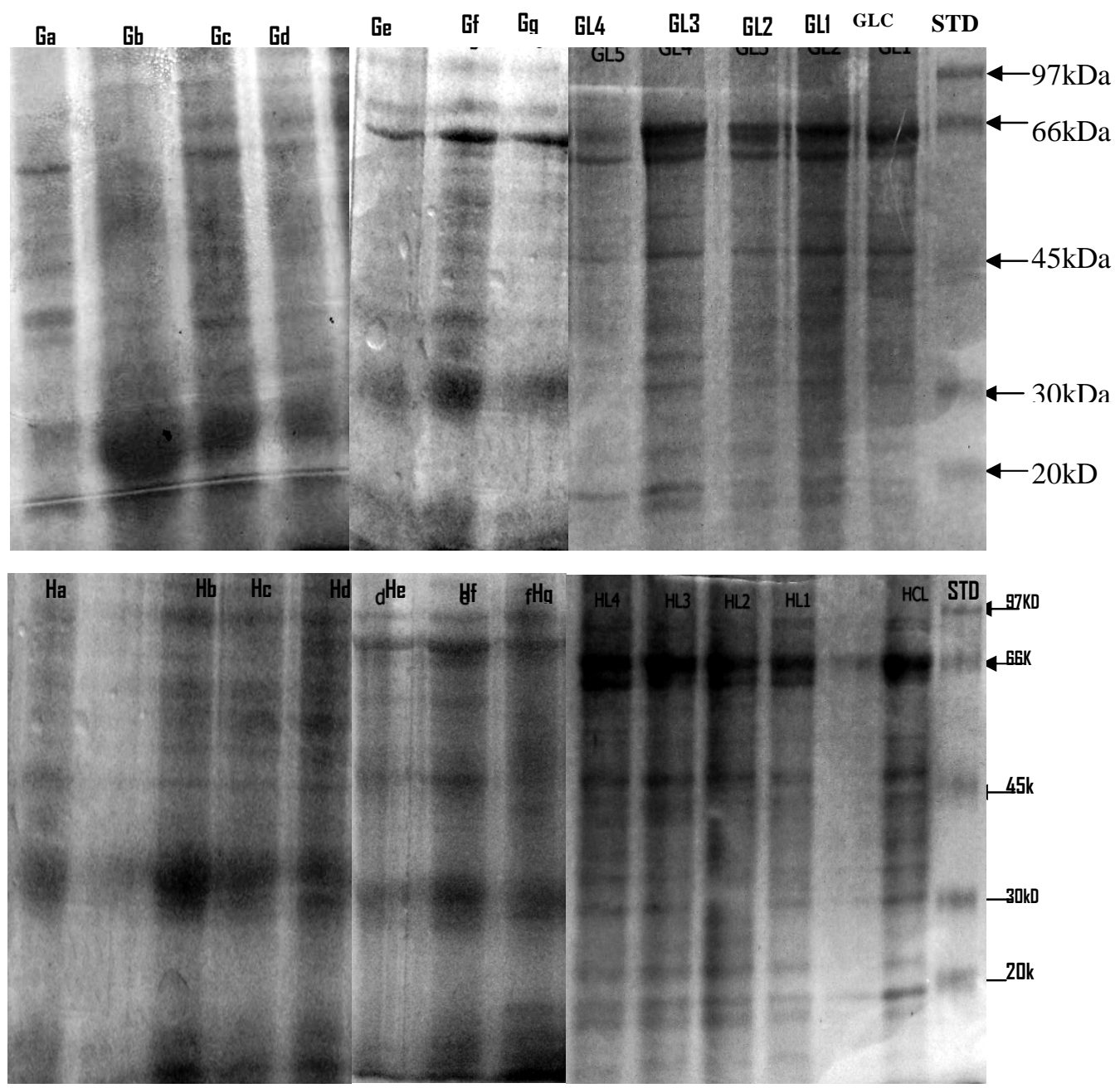

Plate 1. SDS-Poly Acrylamide Gel Electrophoresis Analysis of Bacterial Proins G-Plate consists of E. coli non-O157 (S89) protein bands while H-Plate consists of E. coli O157 (S3B) protein bands

Key: Lane STD-Standard bands: Phosphorylate (97KDa), Bovine serum albumin (66 KDa), Chicken ovalbumin (45KDa), Soyabeans trypsin inhibitor (30KDa), Bovinelactoglobulin (20KDa). Lane Ga and Ha (silver nitrate), Lane $\mathrm{Gb}$ and $\mathrm{Hb}$ (sunlight), Lane $\mathrm{Gc}$ and $\mathrm{Hc}(4 \mathrm{C})$, La ne $\mathrm{Gd}$ and $\mathrm{Hd}\left(20^{\circ} \mathrm{C}\right)$, Lane $\mathrm{Ge}$ and $\mathrm{He}\left(60^{\circ} \mathrm{C}\right)$, Lane Gf and $\mathrm{Hf}\left(50^{\circ} \mathrm{C}\right)$, Lane $\mathrm{Gg}$ and $\mathrm{Hg}\left(40^{\circ} \mathrm{C}\right)$, Lane GL4 and HL4 (pH 8), Lane GL3 and HL3 (pH 7), Lane GL2 and

HL2 (pH 6), GL1 and HL1 (pH 5) and Lane GLC and HLC (Control). ( $R=0.693002, P$ - value $=0.018)$

The effect of different treatments carried out on the two serotypes in this study revealed their ability to survive under various treatment methods. Silver nitrate is toxic to microorganisms and this was confirmed in this study as it inhibited the growth of the two serotypes after an exposure. Studies have revealed that when Escherichia coli is treated or exposed to silver compound, there is a morphological change in its cell membrane which led to increase in its membrane permeability [9]. Hence, leading to improper regulation of transport through the membrane and resulting into cell death. In addition, it is noticed that silver penetrates the bacterial membrane and causes damage by interacting with phosphorus and sulfur containing compounds such as DNA [10]. The DNA loses its replication ability and cellular protein become inactive. Besides, silver compound may react with proteins and bind protein molecules thereby leading to inhibition of cellular metabolism causing death of the microorganism [9]. This explained the protein profile seen after exposure to silver nitrate. 
Studies have shown that there was a significant reduction in coliform forming unit of $E$. coli after exposure to sunlight $[3,11]$. This corroborates the results of this study. The ultraviolet radiation from sunlight creates highly reactive oxygen species such as superoxide $\left(\mathrm{O}^{2-}\right)$, hydrogen peroxides $\left(\mathrm{H}_{2} \mathrm{O}_{2}\right)$, and hydroxyl radicals $\left(\mathrm{OH}^{-}\right)$which in turn oxidizes microbial cellular components such as nucleic acids, enzymes, and membrane lipids, which kills the microorganisms [3].

Effect of low and high temperature on the two serotypes showed that they were able to survive at low temperature even though, their O. D. readings were reduced. It was noticed that the ability of $E$. coli $\mathrm{O} 157$ to survive when exposed to high temperature was much better than the survival of $E$. coli non-O157. This may probably be as a result of the induction of the stress sigma factor, rpoS, which allowed E. coli 0157 to overcome environmental stresses. In a similar study, Ansay et al. [12] reported that E. coli O157:H7 survived freezing with some decline in concentration. Equally, Clavero and Beuchat [13], recovered 5 strains of $E$. coli $0157: \mathrm{H} 7$ at holding temperature of $60^{\circ} \mathrm{C}$ for 0,15 and 30 minutes by using a non-selective medium (Trypticase Soy Broth), with decrease in the microbial load in the samples, as the heating time increased. This signifies that, $E$. coli O157:H7 could survive at temperatures above $45^{\circ} \mathrm{C}$.

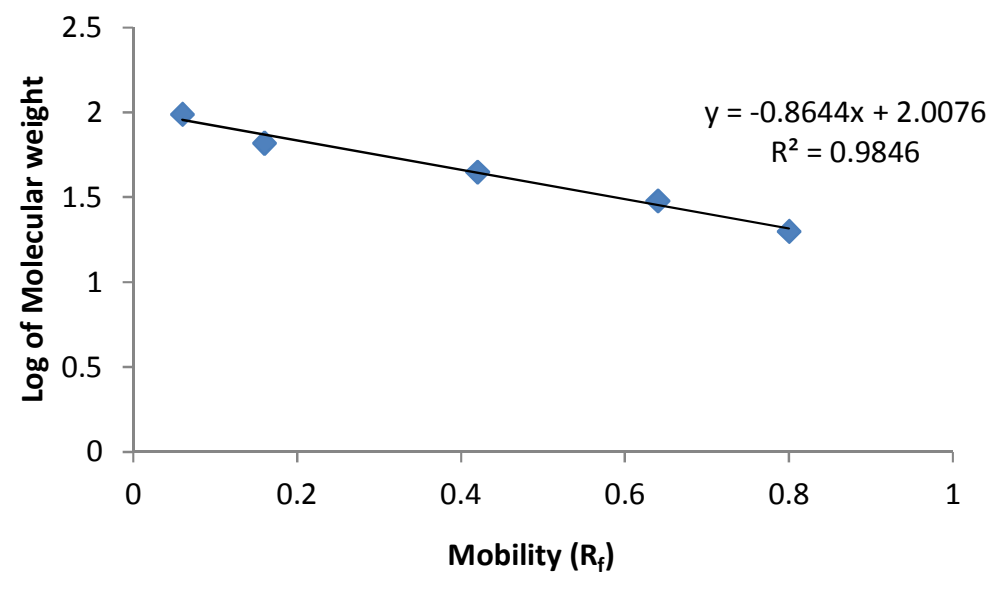

Fig. 1. E. coli 0157 Standard Curve for Determination of Molecular Weight of an Unknown Protein by SDS- PAGE

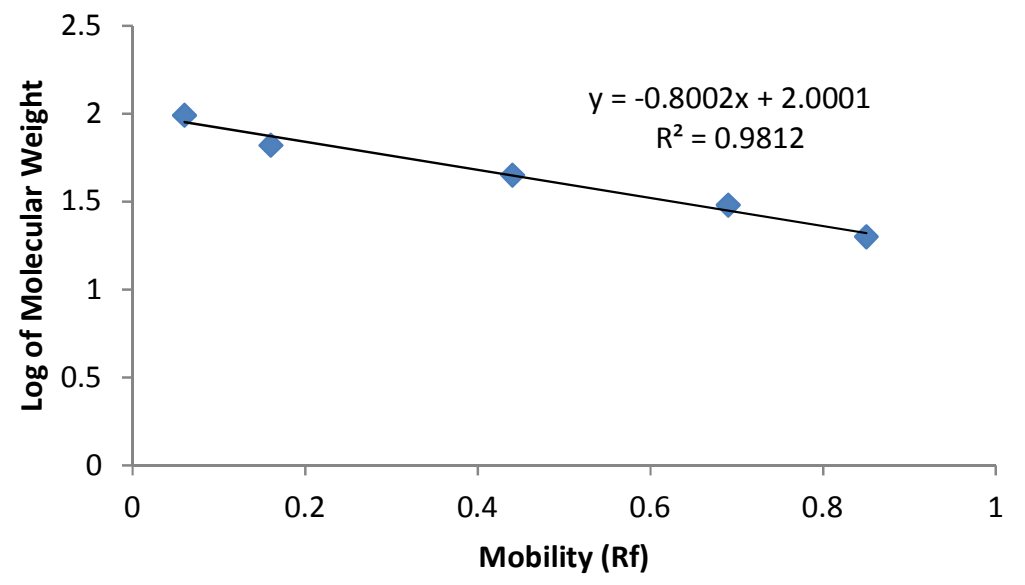

Fig. 2. E. coli non-0157Standard Curve for Determination of Molecular Weight of an Unknown Protein by SDS-PAGE 
The observation that of $E$. coli 0157 survived better than $E$. coli non-O157 at low pH in this study confirmed the findings of other researchers who also reported the survival of E. coli O157 in a slightly acidic medium $[7,14,15]$. Although, $E$. coli $\mathrm{O} 157$ strains still showed different capacities to survive in acidic environment, they are superior in their survival over E. coli non-O157 [16]. Variation in rpoS induction levels might explain the variability in acid resistance of different E. coli O157: $\mathrm{H} 7$ serotypes [6].

In this study, analysis of protein profile pattern of the two serotypes has been used to distinguish between their characteristic responses towards treatment conditions [17]. This was clarified by Berber [18] who stated that chemical characteristics based on comparative analysis of protein profile can be used for rapid microbial identification. Other researchers have also stated that SDS-PAGE protein profiling is a unique molecular tool which can be trusted and can be repeated with good separation power which has been widely used to identify various microorganisms for taxonomic and epidemiological purposes and in animals for phylogenetic relationship $[17,19,20,21,22]$. The similarity in molecular weights of their protein bands corroborates the study by Durrani et al. (8) who also recorded similar molecular weights of protein bands of $E$. coli isolated from stool and urine samples. In a similar study, Chong et al. [23] and Elshayeb et al. [24] also recorded similar protein profile pattern of $E$. coli in their studies.

\section{CONCLUSION}

The treatment methods adopted in this study on the test organisms exerted an inhibitory effect on the organisms. This was also buttressed by the protein profile pattern expressed after treatments. In conclusion, the study showed that E. coli 0157 survived better than E. coli nonO157 following exposure to the treatment methods.

\section{COMPETING INTERESTS}

Authors have declared that no competing interests exist.

\section{REFERENCES}

1. Olowe BM, Oluyege JO, Famurewa O. Prevalence of waterborne diseases and microbial assessment of drinking water quality in Ado-Ekiti and its environs, Southwestern, Nigeria. British Microbiol. Res. J. 2016;12(2):1-13.

2. Yisa J, Jimoh TO, Oyibo OM. Underground water assessment using water quality index. Leonardo J. Sci. 2012;21(6-12):3342.

3. Esemikose EE, Azeez Z. Effects of solar disinfection on Escherichia coli and Klebsiella pneumoniae isolated from water samples. Futa J. Res. Sci. 2013;2:293296.

4. Harry HTM. Measuring E. coli gene expression during human urinary tract infections. MDPI Pathogens. 2016;5(7):19.

Available:www.mdpi.com/journal/pathogen $\underline{\mathbf{s}}$

5. Ravva SV, Cooley MB, Sarreal CZ, Mandrell RE. Fitness of outbreak and environmental strains of Escherichia coli O157:H7 in aerosolizable soil and association of clonal variation in stress gene regulation. Pathogens. 2014;3:528548.

6. Huang $Y$, Kan B, Lu Y, Szeto S. The effect of osmotic shock on rpos expression and antibiotic resistance in Escherichia coli. J. Exp. Microbiol. Immunol. 2009;13:13-17.

7. Albashan MM. Acid tolerance of Escherichia coli O157: H7 serotype and Salmonella typhi (A group D serotype) and their survival in apple and orange juices. World J. Med. Sci. 2009;4(1):33-40.

8. Durrani R, Abubakar M, Arshed MJ, Saleha S, Ullah I, Ali Q. Biological characterization and protein profiles of two model bacteria by SDS-PAGE and FT-IR. ARPN J. Agric. Biol. Sci. 2009;3(5\&6):616.

9. Raffi M, Hussain F, Bhatti TM, Akhter JI, Hameed A, Hasan MM. Antibacterial characterization of silver nanoparticles against E. coli ATCC-15224. J. Mater. Sci. Technol. 2008;24(2):192-196.

10. Feng F, Goto D, Yan T. Effects of autochthonous microbial community on the die-off of fecal indicators in tropical beach sand. FEMS Microbiol. Ecol. 2010;74:214225.

11. Wcisło R, Chrost RJ. Survival of Escherichia coli in freshwater. Polish Journal of Environmental Studies. 2000; 9(3):215-222.

12. Ansay SE, Darling KA, Kaspar CW. Survival of Escherichia coli $\mathrm{O} 157: \mathrm{H} 7$ in 
ground-beef patties during storage at 2, -2 , 15 and then -2 degrees $C$, and -20 degrees. C. J. Food Prot. 1999; 62(11):1243-7.

13. Clavero MRS, Beuchat LR. Survival of Escherichia coli $\mathrm{O} 157: \mathrm{H} 7$ in broth and processed salami as Influenced by $\mathrm{pH}$, water activity, and temperature and suitability of media for its recovery. App. Env. Microbiol. 1996;62(8):2735-2740.

14. Oshoma CE, Aghimien MO, Bello ZO. Growth and survival of Escherichia coli in Kunun Zaki during storage. World J. Agri. Sci. 2009;5(4):494-497.

15. Parry-Hansona AA, Joosteb P, Buysa EM. Relative gene expression in acid-adapted Escherichia coli O157:H7 during lactoperoxidase and lactic acid challenge in tryptone soy broth. Microbiol. Res. 2010;165:546-556.

16. Berghloz TM, Whittam TS. Variation in acid resistance among enterohaemorrhagic $E$. coli in simulated gastric environmented. J. App. Microbiol. 2007;102:352-362.

17. Suardana W, Pinatih KJP, Ratnawati NKA, Widiasih DA. Protein profile analysis of Escherichia coli 0157:H7 from human and animal's origin. Int. J. Curr. Microbiol. Appl. Sci. 2013;2(6):204-214.

18. Berber I. Characterization of Bacillus species by numerical analysis of their SDS-PAGE protein profiles. J. Cell and Mol. Bio. 2004;3:33-37.

19. Celibi A, Duran N, Ozturk F, Acik L, Aslan G, Aslantas O. Identification of clinic urophatogen Escherichia coli isolates by antibiotic susceptibility, plasmid and whole cell protein profiles. Advance Mol. Biol. 2007;1:31-40.

20. Sayed NHM. Phylogenetic relationship among five geckos from Egypt based on RAPD-PCR and protein electrophoresis (SDS-PAGE). J. Basic and App. Zoology 2012;65(3):184-190.

21. Zehr ES, Lavrov DV, Tabatabai LB. Comparison of Haemophilus parasuis reference strains and field isolates by using random amplified polymorphic DNA and protein profiles. BioMed Central. 2012;12:108.

22. Vijaya BR, Sasikala MP, Karthik A. Identification of Escherichia coli isolates from meat samples by antibiotic susceptibility, plasmid DNA and whole cell protein fingerprinting. Int. J. Pharm. Chem. Biol. Sci. 2012;2(4):705-712.

23. Chong BE, Wall DB, Lubman DM, Flynn SJ. Rapid profiling of $E$. coli proteins up to $500 \mathrm{kDa}$ from whole cell lysates using matrix-assisted laser desorption/ionization time-of-flight mass spectrometry. Rapid Comm. Mass Spect. 1997;11:19001908.

24. Elshayeb AA, Yagoub SO, Yousif AS, Abedalkareem EA, EI hag SM, Elagib AA. Identification of protein profiles of Escherichia coli, Staphylococcus aureus and their corresponding phages. American J. Biotechn. Mol. Sci. 2011;1(2):3944.

(c) 2017 Olowe et al.; This is an Open Access article distributed under the terms of the Creative Commons Attribution License (http://creativecommons.org/licenses/by/4.0), which permits unrestricted use, distribution, and reproduction in any medium, provided the original work is properly cited.

Peer-review history:

The peer review history for this paper can be accessed here: http://sciencedomain.org/review-history/19862 